\title{
GENDER DAN REVOLUSI INDUSTRI 4.0 DALAM PENDIDIKAN
}

\author{
Maulana Arafat Lubis \\ IAIN Padangsidimpuan \\ maulanaarafat62@gmail.com
}

\begin{abstract}
The aim of this research is to know the role of gender in utilizing technology in the era of the industrial revolution 4.0 in education. The subject of this research the student of PGMI IAIN Padangsidimpuan. This field research is qualitative where it looks for and uses descriptive data such as words, opinion from research subject either oral or writing. Method of observation, interview and documentation are used to collect the data. Data reduction, data presentation, and conclusions are used as analysis techniques. Data analysis is conducted while data are collected and after the research is done. The result of this research shows that gender (students of PGMI IAIN Padangsidimpuan) and era of industrial revolution is 4.0 in education, this department has learning system based on very good technology in supporting student's knowledge toward current development. So far, students are demanded in conducting academic activities by using technology such as making task report, using academic system, and private online learning. However, the dean of Tarbiyah and Teacher's Training Faculty IAIN Padangsidimpuan gives recommendation so all lecturers of PGMI department always provides teaching of subject by using technology and the learning continues. The interest is so that PGMI IAIN Padangsidimpuan becomes bridge for gender (male or female students) in developing the knowledge and skill based on technology in facing opportunities in the era of industrial revolution 4.0 and is able to be quality human in advancing the names of study programs and institutions in the world of education.
\end{abstract}

Keywords: Gender, Industrial Revolution 4.0, Education 


\section{PENDAHULUAN}

Berdasarkan Undang-Undang Republik Indonesia No. 12 tahun 2012 pasal 13 ayat 2 tentang Pendidikan Tinggi berisikan bahwa mahasiswa/i secara aktif mampu mengembangkan potensi dalam pembelajaran, mencari kebenaran ilmiah, penguasaan, pengembangan, pengamalan suatu cabang ilmu pengetahuan dan teknologi untuk menjadi ilmuwan, intelektual, praktisi, dan profesional yang berbudaya. Untuk itu, sarana dalam memperoleh ilmu pengetahuan hanyalah melalui pendidikan.

Pendidikan sebagai sarana penting untuk meningkatkan kualitas Sumber Daya Manusia (SDM) dalam menjamin keberlangsungan pembangunan suatu bangsa, sebab pendidikan merupakan instrumen utama pengembangan SDM. Pengembangan SDM ini bukan hanya berdasarkan kualitas seseorang dalam menguasai suatu keterampilan khusus, namun terlebih lagi dapat menjadi manusia yang dapat diandalkan (desirable person quality). ${ }^{1}$

Pendidikan sangat penting bagi setiap manusia. Pendidikan dapat membentuk manusia menuju kebaikan, baik di dunia maupun di akhirat. Manusia sangat membutuhkan ilmu melalui pendidikan. Setiap agama khususnya Islam, mengharuskan setiap manusia untuk menuntut ilmu dari dalam kandungan sampai akhir hayatnya. Penanaman dasar pendidikan diawali dengan membentuk akhlak atau karakter seorang. ${ }^{2}$

Adapun yang menjadi isu terkait pendidikan yaitu tantang dan peluang memperoleh pendidikan di era revolusi industri 4.0. Kadang kala teknologi menjadi kebutuhan dalam mempermudah pencarian ilmu pengetahuan maupun membantu pekerjaan. Bagi seseorang yang masih awam, teknologi menjadi sesuatu yang menyakitkan maupun tantangan. Tapi sebaliknya, bagi orang yang melek teknologi akan menjadi suatu peluang dalam memanfaatkan di setiap kondisi. Maka dari itu mahasiswa/i agar melek terhadap teknologi sebagaimana tuntutan zaman dan perkembangan dunia pendidikan.

${ }^{1}$ M. A. Lubis., "Pengembangan Bahan Ajar Komik Berbasis Model Problem Based Learning untuk Meningkatkan Hasil Belajar PKn Siswa Kelas V MIN Medan Sunggal" (Universitas Negeri Medan, 2016), 1, http://digilib.unimed.ac.id/8270/.

${ }^{2}$ M. A. Lubis., "The Using of Comic As A Teaching Material in Building Character of Elementary School Students," JMIE: Journal of Madrasah Ibtidaiyah Education 1, no. 2 (2017): 247, http://e-journal.adpgmiindonesia.com/index.php/jmie. 
Industri 4.0 adalah nama tren otomasi terkini dalam teknologi. Istilah ini mencakup sistem siber-fisik, internet untuk segala, komputasi awan dan komputasi kognitif. Istilah industri 4.0 berasal dari sebuah proyek dalam strategi teknologi canggih pemerintah German yang mengutamakan komputerisasi pabrik. Istilah industri 4.0 diangkat kembali di Hannover Fair pada tahun 2011. Pada bulan Oktober 2012, Working Group on Industry 4.0 memaparkan rekomendasi pelaksanaan industri 4.0 kepada pemerintah federal German. ${ }^{3}$ Sedangkan revolusi industri 4.0 merupakan zaman yang di dalamnya menyangkut kecerdasan buatan manusia, zamannya teknologi, dan inovasi dengan perkembangan sangat cepat yang berpengaruh terhadap pendidikan, perekonomian, perindustrian, pemerintahan, dan perpolitikan. Revolusi industri 4.0 juga era yang di dalamnya terdapat super teknologi serta inovasi terdepan sehingga menjadi dampak perubahan terhadap pendidikan. Gejala tersebut ditandai dengan banyaknya sumber informasi, sumber belajar, maupun menjadi media melalui jejaring sosial secara daring.

Revolusi industri 4.0 menjadi era yang membentuk paradigma manusia untuk bergantung kepada teknologi, karena teknologi sudah menjadi kebutuhan hidup seseorang sekarang ini. Kebutuhan manusia berbisnis mempengaruhi pola dan gaya seseorang misalnya saja, sekarang untuk membeli pakaian tidak perlu lagi pergi ke mall, cukup pesan melalui aplikasi seperti Shopee, Lazada, Zalora dan lain-lain. Selain itu dalam dunia pendidikan juga ada, misalnya untuk melakukan bimbingan privat belajar tidak perlu lagi pergi ke lokasi, cukup menunggu di rumah guru akan datang sendirinya melalui aplikasi seperti ruang guru. Selanjutnya teknologi juga menerapkan tutorial pendidikan ini dengan privat dan classical. Tanpa teknologi seseorang tidak mampu melakukan apapun, baik dalam komunikasi maupun mencari informasi. Teknologi yang dimaksud ialah jaringan internet berupa whatsapp, youtube, email, telegram, facebook, instagram, google, dan lainnya.

Perkembangan ilmu pengetahuan dan teknologi membawa dampak pada gender yang semakin kompleks. Revolusi industri 4.0 termasuk era yang ditandai dengan pesatnya perkembangan teknologi informasi dan komunikasi (TIK). Melalui perkembangan teknologi

${ }^{3}$ F. Julfiati, “Implementasi Usaha-Usaha Kesejahteraan Sosial di Era Digital Revolusi Industri 4.0," ESIT: Jurnal Teknologi Informasi 14, no. 1 (2019): 62, http://www.jurnaleresha.ac.id/index.php/esit/article/view/90/61. 
informasi dan komunikasi, pengambilan, penyebaran, dan penyajian informasi dapat dilakukan secara cepat dan akurat. Pengaruh positif perkembangan teknologi informasi dan komunikasi terhadap aspek kehidupan manusia dapat mendorong perkembangan pendidikan.

Teknologi sudah menjadi salah satu media penting di dunia pendidikan khususnya perguruan tinggi dalam memudahkan proses pembelajaran secara daring ataupun non daring, teknologi yang dimaksud ialah internet. Internet memiliki pengaruh bagi kemajuan pendidikan, salah satunya dalam lingkup perguruan tinggi. Salah satu yang menjadi titik letak kemajuan perguruan tinggi ialah dengan menggunakan teknologi. Selain untuk pengembangan dan penerapan strategi pembelajaran yang inovatif, internet juga digunakan mahasiswa untuk kegiatan akademik di kampus.

Menristekdikti ${ }^{4}$ berpendapat bahwa dalam menghadapi era revolusi industri 4.0 beberapa hal yang harus dipersiapkan, yaitu:

1. Persiapan sistem pembelajaran yang lebih inovatif untuk menghasilkan lulusan yang berkompeten dan terampil. Hal ini diutamakan pada aspek literasi data, literasi teknologi, dan literasi manusia.

2. Rekonstruksi kebijakan lembaga pendidikan tinggi yang adaptif dan responsif terhadap revolusi industri 4.0 dalam mengembangkan transdisiplin ilmu dan program studi yang dibutuhkan.

3. Persiapan sumber daya manusia yang responsif, adaptif, dan handal dalam menghadapi revolusi industri 4.0.

4. Peremajaan sarana dan prasarana dalam pembangunan infrastruktur pendidikan, riset, dan inovasi juga perlu dilakukan untuk menopang kualitas pendidikan.

Maka dapat disimpulkan yang ditarik dari pendapat Menristekdikti di atas, bahwa era revolusi industri 4.0 bukan zaman yang perlu ditakuti, tapi harus dihadapi. Oleh sebab itu perguruan tinggi penting mengajarkan pembelajaran yang berbasis teknologi, agar mahasiswa/i mampu memanfaatkan teknologi dalam memperoleh ilmu pengetahuan sehingga menjadi seseorang yang dapat memajukan perguruan tinggi di

4 Syamsuar \& Reflianto, "Pendidikan dan Tantangan Pembelajaran Berbasis Teknologi Informasi di Era Revolusi Industri 4.0," E-Tech: Jurnal Ilmiah Teknologi Pendidikan 6, no. 2 (2018): 8, http://ejournal.unp.ac.id/index.php/e-tech/article/view/101343/100535\#. 
dunia pendidikan dan membawa nama baik bangsa Indonesia. Untuk memajukan pendidikan tidak ada perbedaan pada gender, karna pada hakikatnya semua manusia berhak memperoleh pendidikan selagi mereka mampu belajar dengan sungguh-sungguh.

Gender berasal dari bahasa latin, yakni genus yang berarti jenis. Gender merupakan ciri-ciri peran dan tanggung jawab yang dibebankan kepada laki-laki dan perempuan lalu ditentukan secara sosial. Menurut Showalter ${ }^{5}$ gender merupakan pembeda laki-laki dan perempuan dilihat dari konstruksi sosial budaya. Sedangkan menurut Santrock gender merupakan dimensi sosiokultural dan psikologis dari pria dan wanita. Istilah gender dibedakan dari jenis kelamin, yaitu laki-laki dan perempuan. Peran gender (gender role) merupakan ekspektasi sosial yang merumuskan cara laki-laki dan perempuan dalam berpikir dan berbuat. Sedangkan menurut Arends, gender merupakan seperangkat perbedaan lain yang ditemukan di kelas-kelas secara beragam. Secara tradisional, keprihatinankeprihatinan mengenai jenis kelamin berfokus pada bias gender melawan perempuan, cara laki-laki dan perempuan bersosialisasi, perbedaan antara laki-laki dan perempuan dalam kemampuan verbal dan teknologi. ${ }^{6}$

Berdasarkan gender, laki-laki dan wanita memiliki kesetaraan dalam hal kesempatan maupun peluang yang sama sebagai sumber perkembangan khususnya bidang pendidikan. Kesetaraan merupakan sepadan ataupun sejajar pekerjaan yang harus dilakukan dalam tujuan untuk pembangunan.

Kesetaraan gender menjadi sorotan dalam rangka memajukan pendidikan di Indonesia. Dapat dilihat dari sudut pandang kemampuan secara knowledge laki-laki dan perempuan dalam kapasitas dan potensinya sama, sehingga laki-laki dan perempuan dapat dipandang setara. Sedangkan jika dicermati secara spesifik kemampuannya sangat berbeda dari segi bentuk. Kesetaraan ini mengindikasikan bahwa laki-laki dan

${ }^{5}$ Elaine Showalter, Speaking of Gender (London: Roudledge, 1989), 3.

${ }^{6}$ H. Alimuddin \& A. Trisnowali, "Profil Kemampuan Spasial dalam Menyelesaikan Masalah Geometri Siswa yang Memiliki Kecerdasan Logis Matematis Tinggi Ditinjau dari Perbedaan Gender," in Prosiding Seminar Nasional Pendidik dan Pengembang Pendidikan Indonesia dengan Tema "Peningkatan Profesionalisme Pendidik di Era Revolusi Industri 4.0" (Nusa Tenggara Barat: Asosiasi Pendidik dan Pengembang Pendidikan Indonesia (APPPI) Wilayah Provinsi Nusa Tenggara Barat sekaligus Kerjasama Himpunan Pengembang Kurikulum Indonesia Wilayah Provinsi Nusa Tenggara Barat, 2018), 24, http://ejournal.apppintb.org/index.php/Prosiding/article/view/26/91. 
perempuan harus mempunyai kapasitas, kesukaan, dan kebutuhan yang sama, sehingga idealnya mereka harus meraih tingkat kesehatan, pendidikan, pendapatan, partisipasi politik yang sama juga. ${ }^{7}$

Posisi perempuan selama ini di masyarakat selalu berada di belakang laki-laki. Posisi yang sangat tidak menguntungkan bagi perempuan untuk mengembangkan dirinya. ${ }^{8}$ Walaupun opini di masyarakat kebanyakan beranggapan seperti itu, tapi di zaman sekarang perempuan tidak lagi berbeda dengan laki-laki dalam memperoleh maupun melakukan segala sesuatu. Sebagaimana yang disampaikan Yohana Yembise ${ }^{9}$ selaku Menteri Pemberdayaan Perempuan dan Perlindungan Anak menyampaikan sambutannya pada saat seminar nasional yang diselenggarakan di Universitas Negeri Yogyakarta bahwa timbulnya revolusi industri 4.0 dapat difungsikan dan dikendalikan/dioperasikan sebaik mungkin oleh barisan perempuan, karena memiliki peluang yang menjanjikan bagi posisi perempuan sebagai bagian dari peradaban dunia. Meskipun masih ada sejumlah tantangan dalam menarik tenaga kerja profesional perempuan untuk bekerja di dunia industri. Menurut studi dari UNESCO pada tahun 2015, lemahnya tingkat partisipasi pekerja perempuan di bidang industri salah satunya disebabkan oleh pemahaman lingkungan kerja di industri merupakan ranah pekerja laki-laki, yang melibatkan pekerja fisik dan tidak menarik bagi pekerja perempuan. Selain itu, masih banyak lulusan perempuan yang memperoleh gelar terkait industri sains, teknologi, dan lain-lain yang memiliki kemungkinan lebih kecil untuk mengejar karier di industri dibandingkan laki-laki. Maka di sinilah dibutuhkan peran perguruan tinggi dalam menggali potensi barisan perempuan agar menjadi lulusan yang mampu menghadapi persaingan di era revolusi industri 4.0. Selain berperan di masyarakat, perempuan juga harus bisa menjadi pendidik yang dapat mengajar, membimbing, dan membentuk anak-anak sebagai generasi yang mampu menjadikan negara bermartabat.

7 D. E Wibowo, "Peran Ganda Perempuan dan Kesetaraan Gender," Jurnal Gender 3, no. 1 (2011): 356-364.

8 Astuti \& T. Marhaeni, Konstruksi Gender dalam Realitas Sosial (Semarang: Unnes Press, 2011), 18.

9 “Daya Saing Perempuan di Era Revolusi Industri 4.0," Kementerian Pemberdayaan

Perempuan dan Perlindungan Anak Republik Indonesia, 2018, https://www.kemenpppa.go.id/index.php/page/read/29/1708/daya-saing-perempuan-diera-revolusi-industri-4-0. 
Adapun penelitian yang relevan pernah dilakukan oleh Kusuma ${ }^{10}$ tentang Penggunaan Internet oleh Dosen Berdasar Gender dan Generasi. Menurutnya, pemakaian internet tidak dipengaruhi oleh faktor gender, melainkan lebih kepada faktor generasi. Ini disebabkan kedua gender memiliki lingkungan pekerjaan yang mengharuskan mengakses teknologi yang sama. Penelitian lain yang relevan juga dilakukan oleh Novianto ${ }^{11}$ tentang Perilaku Penggunaan Internet di Kalangan Mahasiswa. Menurutnya, mahasiswa cenderung menggunakan internet karena adanya kebutuhan informasi ilmiah terkait dengan kepentingan akademik kampus seperti tugas perkuliahan, hasil penelitian, jurnal, dan artikel ilmiah. Tidak hanya itu, mereka juga menggunakan media internet untuk berkomunikasi dengan sesama melalui jejaring sosial seperti facebook, twitter, email, dan lain-lain. Maka dari itu ia beranggapan bahwa tujuan dari penggunaan internet yang dilakukan mahasiswa adalah memanfaatkan sesuatu yang bermanfaat salah satunya untuk menunjang penyelesaian tugas kuliah ataupun tugas akhir dalam menyusun skripsi maupun memperkaya sumber belajar.

Berdasarkan latar belakang di atas, peneliti beranggapan perlu dilakukannya penelitian dengan judul "Gender dan Revolusi Industri 4.0 dalam Pendidikan Tahun 2019". Penelitian ini bertujuan untuk mendeskripsikan perlakuan gender (mahasiswa/i PGMI IAIN Padangsidimpuan) di era revolusi industri 4.0 terhadap pendidikan.

\section{METODE PENELITIAN}

Penelitian ini adalah penelitian lapangan (field research) yang bersifat deskriptif dengan menggunakan pendekatan fenomenologis yang bertujuan untuk mencari realita di lapangan ataupun lokasi tempat yang akan dilakukannya penelitian. Sebagaimana yang diungkapkan Hasbiansyah $^{12}$ bahwa fenomenologi juga berupaya mengungkapkan

${ }^{10}$ R. S. Kusuma, "Penggunaan Internet oleh Dosen Berdasar Gender dan Generasi," Komuniti: Jurnal Komunikasi dan Teknologi Informasi 8, no. 1 (2016): 61, http://journals.ums.ac.id/index.php/komuniti/article/view/2935/1875.

${ }^{11}$ I. Novianto, "Perilaku Penggunaan Internet di Kalangan Mahasiswa," Journal Universitas Airlangga 2, no. 1 (2013): 33-34, http://www.journal.unair.ac.id/filerPDF/Jurnal IIK Novianto.pdf.

${ }_{12}$ M. Masnun, S. Maufur, dan A. Arifuddin, "Respon Stakeholders Terhadap Kurikulum Berbasis Kerangka Kualifikasi Nasional Indonesia (KKNI) Jurusan PGMI IAIN Syekh Nurjati Cirebon," AL IBTIDA: Jurnal Pendidikan Guru MI 5, no. 1 (2018): 29, https://doi.org/10.24235/al.ibtida.snj.v5i1.2479. 
tentang makna dari pengalaman seseorang. Menurut Creswell ${ }^{13}$ penelitian kualitatif ialah suatu proses penelitian dan pemahaman yang berdasarkan metodologi yang mengidentifikasi realita sosial dan problem manusia. Sedangkan menurut Bogdan dan Taylor mengungkapkan bahwa metode kualitatif sebagai prosedur penelitian yang menghasilkan deskripsi berupa perkataan yang dituangkan secara tertulis ataupun disampaikan secara lisan dari narasumber dan perilaku yang diamati di lapangan. ${ }^{14}$ Oleh sebab itu, penelitian ini memfokuskan untuk mengetahui seberapa sering teknologi dimanfaatkan oleh gender (mahasiswa laki-laki dan perempuan). Dari analisa data akan diperoleh hasil tentang gambaran aktivitas gender dalam memanfaatkan teknologi sebagai keperluan belajar.

Penelitian ini bertempat di Program Studi Pendidikan Guru Madrasah Ibtidaiyah (PGMI) Fakultas Tarbiyah dan Ilmu Keguruan IAIN Padangsidimpuan provinsi Sumatera Utara. Kemudian rentang waktu yang diperlukan pada penelitian ini ialah selama 3 bulan, yaitu dari bulan Maret sampai dengan Mei 2019. Untuk menentukan sumber data pada penelitian ini digunakan teknik sampel dengan jenis purposive sampling, yang mana dilakukannya pengambilan sampel sumber data dengan pertimbangan tertentu, pertimbangan tertentu ini adalah orang yang dianggap paling tahu tentang apa yang diharapkan peneliti. ${ }^{15}$

Adapun teknik mengumpulkan data dalam penelitian ini menggunakan observasi, wawancara, dan dokumentasi. Metode observasi dilakukan untuk mengamati secara langsung apa yang terjadi di tempat penelitian dilaksanakan. Metode wawancara dilakukan sebagai metode pengumpulan data paling terpenting, sebagaimana pendapat Singh ${ }^{16}$ bahwa wawancara ialah situasi tatap muka antara peneliti dan sumber data untuk menggali informasi yang diharapkan, sekaligus bertujuan mendapatkan data tentang responden minimum bias dan maksimum efisiensi.

${ }_{13}$ J. W. Creswell, Qualitative Inquiry and Research Design: Choosing Among Five Tradition (London: Sage Publication, 1998), 15.

${ }^{14}$ L. J. Moleong, Metodologi Penelitian Kualitatif, Revisi (Bandung: Remaja Rosda Karya, 2013).

15 Sugiyono, Metode Penelitian Kualitatif dan Kuantitatif (Bandung: Alfabeta, 2012), 118.

${ }^{16}$ L. N. Hakim, “Ulasan Metodologi Kualitatif : Wawancara Terhadap Elit Review of Qualitative Method : Interview of the Elite," 2013, 167. 
Kemudian sumber data dalam penelitian ini adalah mahasiswa Program Studi Pendidikan Guru Madrasah Ibtidaiyah (PGMI) dan Dekan Fakultas Tarbiyah dan Ilmu Keguruan IAIN Padangsidimpuan kota Padangsidimpuan provinsi Sumatera Utara. Prodi ini dipilih karena dianggap lebih familier dan termasuk prodi yang sedang berkembang dalam sistem pembelajarannya dibandingkan dengan prodi lain.

Adapun butir-butir pertanyaan yang akan dilontarkan kepada narasumber diantaranya, yakni pemahaman terhadap internet, pengalaman penggunaan internet dalam membantu proses akademik, tujuan penggunaan internet, media yang sering digunakan dalam membantu tugas perkuliahan, dan web sebagai media untuk mengumpulkan tugas kuliah. Sementara itu metode dokumentasi merupakan cara untuk mengumpulkan data penelitian mengenai hal-hal atau variabel yang berbentuk catatan, transkrip, buku, surat, koran, majalah, prasasti, notulen rapat, leger nilai, agenda, dan lain-lain. ${ }^{17}$ Dokumentasi yang dipakai peneliti berbentuk catatan hasil wawancara dan foto-foto pada saat penelitian berlangsung, baik itu ketika proses wawancara maupun lokasi penelitian.

Setelah data diperoleh, kemudian data diuji keabsahannya menggunakan teknik triangulasi. Triangulasi merupakan teknik pemeriksaan keabsahan data untuk keperluan pengecekan atau pembanding data dari berbagai sumber, dari berbagai waktu, dari berbagai teori, dan dari berbagai metode..$^{18}$ Pada prinsipnya triangulasi ialah model pemeriksaan data untuk menentukan apakah data benar-benar tepat menggambarkan fenomena sebuah penelitian. Peneliti melakukan triangulasi dengan cara membandingkan data yang diperoleh melalui pengaturan waktu dan instrumen yang berbeda, bermaksud membandingkan data hasil tinjauan dengan data hasil wawancara dan menimbang hasil wawancara dengan hasil dokumen. Kemudian analisis

17 J. Dimyati, Metodologi Penelitian Pendidikan dan Aplikasinya pada Pendidikan Anak Usia Dini (PAUD), Pertama (Jakarta: Kencana, 2013), 100, https://books.google.co.id/books?hl=en\&lr=\&id=M-

VNDwAAQBAJ\&oi=fnd\&pg=PA148\&dq=pengertian+dokumentasi+pada+penelitian+kua litatif\&ots=OnjlYt0cPH\&sig=y91a8tqMNCEh5jp_Lf8r-

tvQHKc\&redir_esc $=\mathrm{y} \# \mathrm{v}=$ onepage\& $\mathrm{q}=$ dokumentasi $\& \mathrm{f}=$ false.

${ }^{18}$ B. S. Bachri, "Meyakinkan Validitas Data Melalui Triangulasi Pada Penelitian Kualitatif," Jurnal Teknologi Pendidikan 10, no. 1 (2010): 57, http://yusuf.staff.ub.ac.id/files/2012/11/meyakinkan-validitas-data-melalui-triangulasipada-penelitian-kualitatif.pdf. 
data yang digunakan dalam penelitian ini menerapkan metode deskriptif analitik, yaitu menyusun dengan cara mendeskripsikan, menafsirkan data dan semua hal yang menjadi fokus dalam penelitian. ${ }^{19}$

\section{HASIL DAN PEMBAHASAN}

Tabel 1. Profil Sumber Data

\begin{tabular}{|l|l|l|l|}
\hline No. & Responden (Nama, Semester) & \multicolumn{1}{c|}{ Gender } & \multicolumn{1}{c|}{ Status } \\
\hline 1. & Mahmul, 6 & Laki-laki & Mahasiswa \\
\hline 2. & Hafizah, 4 & Perempuan & Mahasiswi \\
\hline 3. & Lelya Hilda & Perempuan & Dekan \\
\hline
\end{tabular}

Tabel di atas menunjukkan ada 3 sumber data yang dituju untuk mendapatkan informasi secara rill. Adapun penelitian ini menghasilkan beberapa kategori, yaitu: pemahaman terhadap internet, pengalaman penggunaan internet, tujuan penggunaan internet, media yang sering digunakan dalam membantu tugas perkuliahan, web sebagai media untuk mengumpulkan tugas kuliah.

\section{Pemahaman terhadap Internet}

Berdasarkan hasil observasi yang ditemukan di lapangan, peneliti melihat bahwa gender (mahasiswa/i PGMI) secara umum semuanya sangat memahami internet dan cara penggunaannya, hanya saja masih ada gender yang belum memiliki androin, bisa dikatakan masih menggunakan hp kolo-kolo (jadul). Kemudian berdasarkan hasil wawancara kepada sumber data laki-laki, katanya untuk pemahaman internet sudah tidak diragukan lagi, karena internet sudah sering kami gunakan sejak di bangku sekolah, jadi sudah sangat paham akan internet. Ini juga sejalan dari hasil wawancara kepada sumber data perempuan, katanya hampir rata-rata kami sangat memahami internet, jangankan di prodi kami saja, bahkan mungkin anak-anak zaman sekarang pasti sudah paham terhadap internet.

Hasil observasi dan wawancara terhadap gender di atas dapat disimpulkan bahwa meluasnya perkembangan teknologi menjadi pengaruh terhadap pemahaman gender sampai saat ini. Artinya pemahaman gender terhadap internet memiliki kesetaraan.

${ }^{19}$ Masnun, Maufur, dan Arifuddin, "Respon Stakeholders Terhadap Kurikulum Berbasis Kerangka Kualifikasi Nasional Indonesia (KKNI) Jurusan PGMI IAIN Syekh Nurjati Cirebon," 30. 


\section{Pengalaman Penggunaan Internet}

Hasil observasi di lapangan peneliti melihat bahwa sumber data sangat lihai dalam menggunakan teknologi khususnya internet, bahkan setiap hari selalu menggunakan teknologi berupa android, walaupun masih ada gender yang belum memiliki laptop karena faktor ekonomi. Kemudian hasil wawancara kepada sumber data laki-laki, katanya untuk pengalaman penggunaan internet sudah sangat lama sejak awal-awalnya pakai hp 3G sudah dilakukan, karena dulu tu sering gunakan internet untuk BBMan dan facebook. Jadi pengalaman menggunakan internet sudah lama sekali bahkan sampai sekarang. Selanjutnya wawancara kepada sumber data perempuan, katanya pengalaman pakai internet sudah lama sampai sekarang, internet sudah jadi kebutuhan sekali dalam mencari informasi dan lainnya. Contohnya saja, kalua ada tugas PR selalu mencari jalan keluarnya ya menggunakan internet, karna dari sanalah yang cepat buat paham dibandingkan guru yang menjelaskan. Selain itu pengalaman yang berharga kami peroleh internet bisa jadi sumber utama belajar kami dalam perkuliahan.

Hasil observasi dan wawancara di atas dapat disimpulkan bahwa pengalaman yang dilalui gender dalam penggunaan internet sangat banyak memperoleh sifat yang positif, salah satunya memperoleh informasi dan sebagai sumber belajar. Maka artinya pengalaman menggunakan internet yang dialami oleh gender memiliki kesetaraan, yang mana gender memiliki kesamaan dalam segi pengalaman.

\section{Tujuan Penggunaan Internet}

Berdasarkan hasil observasi, peneliti melihat secara umum para gender berpendapat bahwa menggunakan internet memiliki tujuan positif, salah satunya bertujuan dalam hal mempermudah setiap keinginan, pekerjaan, komunikasi, maupun hiburan. Sedangkan hasil wawancara kepada sumber data laki-laki, katanya internet tu tujuannya kalua bagi saya untuk mempermudah cari tugas kuliah yang paling utama, selain itu untuk mencari lokasi dengan GPS kalau mau pergi jalan-jalan. Sedangkan wawancara kepada sumber data perempuan, katanya tujuan saya gunakan internet itu untuk membantu proses pembelajaran. Selain itu tujuan yang sangat penting yaitu komunikasi untuk berbisnis dalam memperoleh uang, contohnya saja dari sebagian kami di prodi PGMI khususnya perempuan ada yang melakukan jual beli pakaian, jadi gak perlu rumit-rumit lagi ke pajak untuk menjualkan atau membeli barang yang kami pingin. Kemudian ada juga dari temen-temen yang diundang untuk menjadi guru privat ya walaupun kami belum sarjana, tapi cukup banyak juga 
masyarakat yang membutuhkan tenaga pengajar biasanya guru mengaji. Ada lagi yang sangat penting tujuan internet bagi kami dalam pengadministrasian akademik, seperti penggunaan SIAKAD (Sistem Akademik) secara daring, sistem ini bertujuan untuk aktivasi NIM (Nomor Induk Mahasiswa) setiap semesternya. Karena dari aktivasi ini kami bisa mengajukan perkuliahan/pembelajaran. Makanya banyak hal yang positif kami dapatkan dalam penggunaan internet.

Maka dapat disimpulkan dari hasil wawancara maupun observasi dari sumber data di atas, yang mana teknologi bisa dimanfaatkan sebagai peluang yang besar, tergantung siapa yang mampu menyetir penggunaan internet dalam kehidupan sehari-hari. Maka dari itu gender dianggap memiliki kesetaraan dalam memandang tujuan penggunaan internet.

\section{Media yang Sering Digunakan}

Berdasarkan observasi di lapangan peneliti melihat media yang paling sering digunakan ialah media sosial berupa whatsapp, facebook, Instagram, youtube. Sedangkan hasil wawancara kepada sumber data lakilaki, katanya kalau untuk komunikasi media yang paling sering digunakan cuman whatsapp. Karna kalau ada info dari kampus dan lain-lain ya sering melalui whatsapp group. Kemudian wawancara kepada sumber data perempuan, katanya media yang sering digunakan untuk perkuliahan yaitu email dan youtube. Karna kadang ada dosen yang nyuruh ngumpulin tugas melalui email, terus juga disuruh buat tugas media pembelajaran berbentuk video kemudian wajib dishare ke youtube dan itu cuman satu mata kuliah, yaitu mata kuliah PPKn kelas rendah SD/MI. Makanya akibat tuntutan itu kita harus sering-sering kepoin kedua media itu, karna nilai tergantung banyaknya like dan subscribe dari publik.

Isi wawancara di atas maka dapat ditarik kesimpulan bahwa teknologi sudah menjadi alat yang sangat penting digunakan di perguruan tinggi, karena majunya perguruan tinggi disebabkan pengembangan yang dilakukan mahasiswa untuk kemajuan dan kejayaan institusi. Maka perlu seorang dosen membimbing dan mewajibkan mahasiswa untuk selalu melek terhadap teknologi, apalagi di era revolusi industri 4.0. kemudian dapat dilihat dari kedua data yang diperoleh bahwa adanya kesetaraan gender, artinya hasil wawancara dari kedua sumber data memiliki kesetaraan, berarti penggunaan media di jejaring internet dalam kalangan mahasiswa di perguruan tinggi kategori stabil.

\section{Web yang digunakan untuk tugas kuliah}

Berdasarkan hasil observasi di lapangan, peneliti melihat secara umum web yang digunakan untuk membantu selesaikan tugas kuliah 
biasanya mencari referensi dari blogspot maupun web yang berdasarkan hasil pencarian di google. Sedangkan hasil wawancara kepada sumber data laki-laki katanya tugas yang sering kami kerjakan itu selalu makalah, jadi referensinya kalau tidak dari buku di perpustakaan pasti dari internet. Tapi lebih seringan dari internet, karena buku-buku yang ada di perpustakaan kami jarang ada, apalagi tentang PGMI/PGSD jarang sekali. Makanya kami sering ambil rujukan untuk tugas makalah selalu dari internet. Web yang sering kami gunakan tu google books dan repositori dari digilib kampus ternama. Selanjutnya hasil wawancara kepada sumber data perempuan, katanya baru-baru ini kami diwajibkan sama dosen mata kuliah PPKn kelas rendah MI/SD untuk mengupload makalah ke web inarxiv.id, academia.edu, dan researchgate. Jadi tidak lagi hanya ke email. Itu bukan hanya tugas makalah saja, semua yang bersifat tugas harus di upload. Itulah yang kadang-kadang membuat kami harus belajar dan mahir dalam berteknologi.

Hasil wawancara di atas dapat disimpulkan bahwa di sela-sela proses pembelajaran harus disertai penggunaan teknologi, ini disebabkan dunia pendidikan butuh perkembangan atau sesuatu yang baru dari eraera sebelumnya, kalau tidak dituntut kepada mahasiswa/i maka mereka tidak akan pernah mengalami. Maka dari itu ada animo yang perlu diimplementasikan sistem belajar di perguruan tinggi, yaitu pembelajaran yang berbasis web. Tanggapan dari kedua gender menunjukkan bahwa adanya kesetaraan yang mana mereka sama-sama membrowsing tugas kuliah melalui web/internet.

Dari hasil observasi dan wawancara yang dilakukan peneliti terhadap gender, ternyata ditanggapi oleh Dekan FTIK IAIN Padangsidimpuan yang juga dijadikan sumber data dalam penelitian ini. Beliau mendefinisikan dari butir-butir wawancara di atas bahwa intinya ialah dari sekarang di FTIK IAIN Padangsidimpuan semua sistem yang mendukung pembelajaran dan administrasi harus disertai teknologi, ini sudah dituntut juga oleh bapak Rektor, bukan hanya mahasiswa saja, akan tetapi seluruh civitas akademika kampus ini harus bisa menggunakan teknologi. Sebentar lagi FTIK akan menyediakan laboratorium computer, gunanya untuk pengembangan keammpuan teknologi di FTIK, jadi nantinya sistem ujian tidak lagi secara manual, tetapi sudah memakai sistem teknologi. Harapannya ialah seluruh dosen mampu menerapkan pembelajaran yang berbasis ICT, karena kita sudah hidup di zaman serba teknologi. Tapi masih ada dosen yang masih menggunakan metode pembelajaran zaman dahulu, tidak ada perkembangan. Maka dari itu nanti seluruh 
dosen akan diberi peringatan untuk mengajar selalu menyertakan teknologi. Memang sarana dan prasarana masih kurang mendukung, akan tetapi pasti kami perbaiki untuk menunjang proses pembelajaran efektif dan efisien.

Hasil penelitian yang sudah dipaparkan di atas menunjukkan secara umum bahwa tanggapan gender terkait penggunaan teknologi berbasis internet di era revolusi industry 4.0 (mahasiswa/i PGMI dan Dekan FTIK IAIN Padangsidimpuan) terhadap pendidikan sudah sangat baik dan tidak ada kesenjangan penggunaan diantara kedua gender, artinya sudah setara dan tidak ada mendominasi. Maka dari itu sistem pembelajaran berbasis teknologi di prodi PGMI sudah sesuai dengan tuntutan revolusi industri 4.0 terhadap kemajuan pendidikan.

\section{PENUTUP}

Berdasarkan uraian hasil penelitian di atas maka dapat disimpulkan bahwa pemahaman gender terhadap internet, pengalaman penggunaan internet, tujuan penggunaan internet, media yang sering digunakan dan web yang digunakan untuk tugas kuliah tidak ada pengaruh, karena kedua gender sama-sama menggunakannya dan tidak ada kesenjangan maupun mendominasi. Ini disebabkan kedua gender memiliki lingkungan yang mengharuskan mereka untuk menggunakan teknologi dan mengakses internet yang sama akibat tuntutan maupun kemauan masing-masing. Hanya saja caranya mengakses yang berbeda, ada yang menggunakan android dan ada juga menggunakan laptop.

\section{DAFTAR PUSTAKA}

Alimuddin, Herman, dan Andi Trisnowali. "Profil Kemampuan Spasial dalam Menyelesaikan Masalah Geometri Siswa yang Memiliki Kecerdasan Logis Matematis Tinggi Ditinjau Dari Perbedaan Gender." In Prosiding Seminar Nasional Pendidik dan Pengembang Pendidikan Indonesia Dengan Tema "Peningkatan Profesionalisme Pendidik di Era Revolusi Industri 4.0," 21-30. Nusa Tenggara Barat: Asosiasi Pendidik dan Pengembang Pendidikan Indonesia (APPPI) Wilayah Provinsi Nusa Tenggara Barat sekaligus Kerjasama Himpunan Pengembang Kurikulum Indonesia Wilayah Provinsi Nusa Tenggara Barat, 2018. http://ejournal.apppintb.org/index.php/Prosiding/article/view/26/91.

Astuti, dan T. Marhaeni. Konstruksi Gender dalam Realitas Sosial. Semarang: Unnes Press, 2011. 
Bachri, B. S. "Meyakinkan Validitas Data Melalui Triangulasi Pada Penelitian Kualitatif." Jurnal Teknologi Pendidikan 10, no. 1 (2010): 46-62. http://yusuf.staff.ub.ac.id/files/2012/11/meyakinkan-validitas-datamelalui-triangulasi-pada-penelitian-kualitatif.pdf.

Creswell, J. W. Qualitative Inquiry and Research Design: Choosing Among Five Tradition. London: Sage Publication, 1998.

“Daya Saing Perempuan di Era Revolusi Industri 4.0." Kementerian Pemberdayaan Perempuan dan Perlindungan Anak Republik Indonesia, 2018. https://www.kemenpppa.go.id/index.php/page/read/29/1708/dayasaing-perempuan-di-era-revolusi-industri-4-0.

Dimyati, J. Metodologi Penelitian Pendidikan dan Aplikasinya Pada Pendidikan Anak Usia Dini (PAUD). Pertama. Jakarta: Kencana, 2013. https://books.google.co.id/books?hl=en\&lr=\&id=M-

VNDwAAQBAJ\&oi=fnd\&pg=PA148\&dq=pengertian+dokumentasi+p ada+penelitian+kualitatif\&ots=OnjlYt0cPH\&sig=y91a8tqMNCEh5jp_L f8r-tvQHKc\&redir_esc $=\mathrm{y} \# \mathrm{v}=$ onepage\&q=dokumentasi\&f=false.

Hakim, L. N. “Ulasan Metodologi Kualitatif : Wawancara Terhadap Elit Review of Qualitative Method : Interview of the Elite," 2013, 165-72.

Julfiati, F. "Implementasi Usaha-Usaha Kesejahteraan Sosial di Era Digital Revolusi Industri 4.0." ESIT: Jurnal Teknologi Informasi 14, no. 1 (2019): $57-67$. http://www.jurnaleresha.ac.id/index.php/esit/article/view/90/61.

Kusuma, R. S. "Penggunaan Internet oleh Dosen Berdasar Gender dan Generasi." Komuniti: Jurnal Komunikasi Dan Teknologi Informasi 8, no. 1 (2016): $53-63$. http://journals.ums.ac.id/index.php/komuniti/article/view/2935/1875. Lubis, M. A. “Pengembangan Bahan Ajar Komik Berbasis Model Problem Based Learning untuk Meningkatkan Hasil Belajar PKn Siswa Kelas V MIN Medan Sunggal." Universitas Negeri Medan, 2016. http://digilib.unimed.ac.id/8270/.

- - - "The Using of Comic As A Teaching Material in Building Character of Elementary School Students." JMIE: Journal of Madrasah Ibtidaiyah Education 1, no. 2 (2017): 246-58. http://ejournal.adpgmiindonesia.com/index.php/jmie.

Masnun, M., S. Maufur, dan A. Arifuddin. “Respon Stakeholders Terhadap Kurikulum Berbasis Kerangka Kualifikasi Nasional Indonesia (KKNI) 
Jurusan PGMI IAIN Syekh Nurjati Cirebon." AL IBTIDA: Jurnal Pendidikan Guru MI 5, no. 1 (2018): 25-38. https://doi.org/10.24235/al.ibtida.snj.v5i1.2479.

Moleong, L. J. Metodologi Penelitian Kualitatif. Revisi. Bandung: Remaja Rosda Karya, 2013.

Novianto, I. "Perilaku Penggunaan Internet di Kalangan Mahasiswa." Journal Universitas Airlangga 2, no. 1 (2013). http://www.journal.unair.ac.id/filerPDF/Jurnal IIK Novianto.pdf.

Showalter, E. Speaking of Gender. London: Roudledge, 1989.

Sugiyono. Metode Penelitian Kualitatif dan Kuantitatif. Bandung: Alfabeta, 2012.

Syamsuar, dan Reflianto. "Pendidikan dan Tantangan Pembelajaran Berbasis Teknologi Informasi di Era Revolusi Industri 4.0." E-Tech: Jurnal Ilmiah Teknologi Pendidikan 6, no. 2 (2018). http://ejournal.unp.ac.id/index.php/etech/article/view/101343/100535\#.

Wibowo, D. E. "Peran Ganda Perempuan dan Kesetaraan Gender." Jurnal Gender 3, no. 1 (2011): 356-64. 